\title{
Mitigation of Natural Disasters as Efforts to Minimize Unwanted Impacts in Baleendah Sub-District, Bandung Regency, Indonesia
}

\author{
Yuyun Hidayat ${ }^{1}$, Sukono $^{2, *}$, Kalfin ${ }^{3}$ \\ ${ }^{1}$ Department of Statistics, Faculty of Mathematics and Natural Sciences, Universitas Padjadjaran, Indonesia \\ ${ }^{2}$ Department of Mathematics, Faculty of Mathematics and Natural Sciences, Universitas Padjadjaran, Indonesia \\ ${ }^{b}$ Doctor Program of Mathematics, Faculty of Mathematics and Natural Sciences, Universitas Padjadjaran, \\ Indonesia
}

Corresponding author e-mail address: sukono@unpad.ac.id

\begin{abstract}
Flood disaster is a natural event, one of which is caused by overflowing rivers. This disaster often occurs in the Majalaya area, Bandung Regency. Geographical conditions close to the Citarum River flow and the plains lower than the surrounding area causes this area to be flooded especially during the rainy season. Through the Community Service Program with the topic "training and simulation of natural disaster mitigation as an effort to minimize unwanted impacts in Majalaya sub-district" aims to increase the knowledge of the surrounding community regarding the impact of flood disasters and efforts to reduce the impact through mitigation efforts. This activity is aimed at 8th graders of SMP Negeri 1 Majalaya by using the presentation method using WhatsApp group media. This activity begins with giving questionnaire I which functions as a pre-test and ends with questionnaire II which functions as a post-test. The questionnaire was given at the beginning and at the end to see to what extent the material gave influence and new knowledge to students of SMP Negeri 1 Majalaya. The results of the questionnaire show that prior to counseling on flood disaster mitigation, the sample was categorized as having good knowledge of $87 \%$ and having poor knowledge of $13 \%$. After counseling about flood disaster mitigation using power point media and games there was an increase in knowledge, the sample with good knowledge was $98 \%$ and those with poor knowledge were $2 \%$. Based on the results of the pre-test and post-test, this activity proved successful in increasing the knowledge of SMP Negeri 1 Majalaya regarding flood mitigation.
\end{abstract}

Keywords: natural disasters, disaster mitigation, flood

\section{Introduction}

The issue of natural disasters has always been hotly discussed, both in developed and developing countries including Indonesia. Natural disasters that occur can be in the form of floods, drought, landslides, tsunamis, earthquakes, and storms (Kusumastuti et al., 2014; Pascapurnama et al., 2018; Viverita et al., 2014). In Indonesia, the incidence of natural disasters continues to increase from year to year. West Java Province is one of the regions in Indonesia in third place, prone to natural disasters. This is based on data from the National Disaster Management Agency (BNPB) for the last five years (2015 S / 
D 2020). Based on data from BNPB, in the first place is Central Java province with 2,646 incidents, then in second place East Java with 1,592 events and for West Java there are 1,184 events. On the other hand, the topography of West Java province, which is hilly and filled with tropical rainforests, is decreasing due to land clearing and forest fires, which has the potential to produce landslides, floods and tornadoes. The consequences of these natural disasters clearly provide huge losses from a socio-economic perspective (Sattler et al., 2018; Pramono et al., 2020; Wardani and Muntohar, 2013; Mardiasmo and Barnes, 2015).

Natural disasters are a problem both in big cities and in villages. Natural disasters that occur can have a large impact on human life, in the form of damage to settlements, casualties and socio-economic impacts (Seyle et al., 2013; Rindrasih et al., 2018; Ginantra et al., 2021). In the village area, especially in Baleendah District, is one of the areas that is directly affected by natural disasters such as floods. As a result of natural disasters experienced by the local community, it has caused new problems such as damage to housing, health problems and others (Pratama and Sumitra, 2020; Kumala Dewi and Dartanto, 2019; Kurniawan et al., 2021).

To minimize the impact of natural disasters, it is necessary to provide understanding to the government and local communities regarding disaster mitigation and management (Yulianto et al., 2021; Kurniasari et al., 2019; Rush, 2018). Disaster management can be done from pre-disaster such as when a disaster does not occur with disaster risk reduction activities, disaster management planning, prevention, education and training. In situations where there is a potential for disaster, the activities carried out include early warning, disaster mitigation and preparedness, then during a disaster or disaster preparedness such as emergency response or evacuation for flood victims and emergency assistance. The last one is postdisaster such as carrying out reconstruction and rehabilitation (Efendi et al., 2019; Pascapurnama et al., 2016).

Therefore, we as academics intend to socialize about disaster mitigation and management through the PPM program. Materials that will be given to PPM activities related to disaster mitigation and management. This material will be given in workshop sessions to both the community and junior high school students.

\section{Materials and Methods}

\subsection{Materials}

The data used in this study are primary data obtained from students of SMPN 1 Majalaya in Majalaya District, Bandung Regency, Indonesia. The data were obtained from questionnaires given to students before and after being given the material workshop. The questionnaire was given regarding students' understanding of natural disaster mitigation according to the workshop topic.

\subsection{Methods}

The method used in this PPM is a Practical Qualitative method which means that the results of intracampus research can be applied directly to the community practically. The understanding given is more to qualitative approaches such as discussion, consultation and joint evaluation. However, the discussion session in SMP gave a little quantitative explanation about disaster mitigation and management. The implementation of workshop activities to minimize the impact of disasters is carried out through WhatsApp group media related to the existence of school regulations in the network, by tuning the stages of activities as follows:

a) Conduct field observations

b) Arrangement of licenses to the related sub-district and junior high school offices in Majalaya District, Bandung Regency and requests to involve students in the implementation of activities.

c) Implementation of activities by providing online workshop materials:

- Disaster contributing factors, both natural and human activities

- Impact of natural disasters from a socio-economic perspective

- Effective disaster management strategy 
- Evaluation of discussion results.

\section{Results and Discussion}

This section discusses the results of the analysis obtained from the questionnaire given to students of SMPN 1 Majalaya. From the results of the questionnaire given to students, the results are in Table 1.

Table 1. Sample Knowledge Value Data

\begin{tabular}{|c|c|c|c|c|c|c|c|c|}
\hline \multirow{2}{*}{ No } & \multirow{2}{*}{ Name } & \multirow{2}{*}{ Class } & \multicolumn{3}{|c|}{ pre test } & \multicolumn{3}{|c|}{ post test } \\
\hline & & & Correct & Wrong & Score & Correct & Wrong & Score \\
\hline 1 & Alykha Reystu Halisha & $8 \mathrm{~A}$ & 7 & 3 & 70 & 7 & 3 & 70 \\
\hline 2 & Angga Ramadan & $8 \mathrm{~A}$ & 8 & 2 & 80 & 8 & 2 & 80 \\
\hline 3 & Azmi Hanan Habibah & $8 \mathrm{~A}$ & 7 & 3 & 70 & 8 & 2 & 80 \\
\hline 4 & Bunga Ayu Lestari & $8 \mathrm{~A}$ & 6 & 4 & 60 & 8 & 2 & 80 \\
\hline 5 & Deni Kurnia Sandi & $8 \mathrm{~A}$ & 5 & 5 & 50 & 6 & 4 & 60 \\
\hline 6 & Dinar Aura Brilian & $8 \mathrm{~A}$ & 8 & 2 & 80 & 8 & 2 & 80 \\
\hline 7 & Dinar Gina Hasanah & $8 \mathrm{~A}$ & 8 & 2 & 80 & 8 & 2 & 80 \\
\hline 8 & Dirly Muhammad Rizky & $8 \mathrm{~A}$ & 7 & 3 & 70 & 8 & 2 & 80 \\
\hline 9 & Faishal Ahmad Fauzi & $8 \mathrm{~A}$ & 7 & 3 & 70 & 7 & 3 & 70 \\
\hline 10 & Fajar Ikhsan Akbar & $8 \mathrm{~A}$ & 7 & 3 & 70 & 8 & 2 & 80 \\
\hline 11 & Kafka Adzelia Fanesha & $8 \mathrm{~A}$ & 7 & 3 & 70 & 7 & 3 & 70 \\
\hline 12 & Karin Izati & $8 \mathrm{~A}$ & 9 & 1 & 90 & 9 & 1 & 90 \\
\hline 13 & Kirania Putri Nurhastya & $8 \mathrm{~A}$ & 5 & 5 & 50 & 5 & 5 & 50 \\
\hline 14 & Lisda Luthfia Azahra & $8 \mathrm{~A}$ & 7 & 3 & 70 & 7 & 3 & 70 \\
\hline 15 & Mariam Anisa Sya'ban & $8 \mathrm{~A}$ & 8 & 2 & 80 & 8 & 2 & 80 \\
\hline 16 & Mellysa Nindia Zahrani & $8 \mathrm{~A}$ & 6 & 4 & 60 & 6 & 4 & 60 \\
\hline 17 & $\begin{array}{l}\text { Mochamad Raihan } \\
\text { Kusnawan }\end{array}$ & $8 \mathrm{~A}$ & 8 & 2 & 80 & 8 & 2 & 80 \\
\hline 18 & Muhamad Rafly Framudya & $8 \mathrm{~A}$ & 7 & 3 & 70 & 7 & 3 & 70 \\
\hline 19 & Muhammad Irfan Nurrohman & $8 \mathrm{~A}$ & 8 & 2 & 80 & 8 & 2 & 80 \\
\hline 20 & Naisya Januarizqi & $8 \mathrm{~A}$ & 7 & 3 & 70 & 8 & 2 & 80 \\
\hline 21 & Nazwa Mauladina & $8 \mathrm{~A}$ & 7 & 3 & 70 & 8 & 2 & 80 \\
\hline 22 & Neng Nadia Sri Mulyani & $8 \mathrm{~A}$ & 7 & 3 & 70 & 8 & 2 & 80 \\
\hline 23 & Nurizqi Sumarni & $8 \mathrm{~A}$ & 8 & 2 & 80 & 9 & 1 & 90 \\
\hline 24 & Rahma Anggelia & $8 \mathrm{~A}$ & 5 & 5 & 50 & 7 & 3 & 70 \\
\hline 25 & Regi Nurdiansah & $8 \mathrm{~A}$ & 7 & 3 & 70 & 7 & 3 & 70 \\
\hline 26 & Reihan Alfarisshi & $8 \mathrm{~A}$ & 5 & 5 & 50 & 7 & 3 & 70 \\
\hline 27 & Rendi Fadilah Kusnandar & $8 \mathrm{~A}$ & 7 & 3 & 70 & 8 & 2 & 80 \\
\hline 28 & Renren Sintya & $8 \mathrm{~A}$ & 7 & 3 & 70 & 7 & 3 & 70 \\
\hline 29 & Rifa Rizqulloh & $8 \mathrm{~A}$ & 8 & 2 & 80 & 8 & 2 & 80 \\
\hline 30 & Riffa Anugrah Muttaqin & $8 \mathrm{~A}$ & 8 & 2 & 80 & 8 & 2 & 80 \\
\hline 31 & Rinaldi Danurwenda & $8 \mathrm{~A}$ & 8 & 2 & 80 & 9 & 1 & 90 \\
\hline 32 & Riska Aprilianti & $8 \mathrm{~A}$ & 8 & 2 & 80 & 9 & 1 & 90 \\
\hline
\end{tabular}




\begin{tabular}{|c|c|c|c|c|c|c|c|c|}
\hline 33 & Rivaldi Saputra & $8 \mathrm{~A}$ & 8 & 2 & 80 & 8 & 2 & 80 \\
\hline 34 & Siti Haenah Ardi & $8 \mathrm{~A}$ & 7 & 3 & 70 & 8 & 2 & 80 \\
\hline 35 & Siti Kein Kiranty & $8 \mathrm{~A}$ & 8 & 2 & 80 & 8 & 2 & 80 \\
\hline 36 & Soni Noviansyah & $8 \mathrm{~A}$ & 8 & 2 & 80 & 8 & 2 & 80 \\
\hline 37 & Syamsul Fabio Taufik & $8 \mathrm{~A}$ & 7 & 3 & 70 & 7 & 3 & 70 \\
\hline 38 & Syauki Azkia Utama & $8 \mathrm{~A}$ & 8 & 2 & 80 & 8 & 2 & 80 \\
\hline 39 & Taufik Jamil & $8 \mathrm{~A}$ & 7 & 3 & 70 & 7 & 3 & 70 \\
\hline 40 & Trisha Alifvia Zahra & $8 \mathrm{~A}$ & 6 & 4 & 60 & 6 & 4 & 60 \\
\hline 41 & Viona Herliana & $8 \mathrm{~A}$ & 9 & 1 & 90 & 9 & 1 & 90 \\
\hline 42 & Zahra Haifa & $8 \mathrm{~A}$ & 7 & 3 & 70 & 8 & 2 & 80 \\
\hline 43 & Khavya Rizkyan Ip & $8 B$ & 4 & 6 & 40 & 6 & 4 & 60 \\
\hline 44 & Natasya Daffa Nabila & $8 B$ & 7 & 3 & 70 & 7 & 3 & 70 \\
\hline 45 & Meyfaaf & $8 B$ & 8 & 2 & 80 & 9 & 1 & 90 \\
\hline 46 & Ferisa Reza Risanti & $8 B$ & 8 & 2 & 80 & 8 & 2 & 80 \\
\hline 47 & Ristry Atrianti Sagita & $8 B$ & 7 & 3 & 70 & 7 & 3 & 70 \\
\hline 48 & Tiara Aqila Zahra & $8 B$ & 6 & 4 & 60 & 6 & 4 & 60 \\
\hline 49 & Maura Fasha Khairunnisa & $8 B$ & 9 & 1 & 90 & 8 & 2 & 80 \\
\hline 50 & Cintami & $8 B$ & 8 & 2 & 80 & 8 & 2 & 80 \\
\hline 51 & Neng Jihan & $8 B$ & 7 & 3 & 70 & 8 & 2 & 80 \\
\hline 52 & Savira Prazendie & $8 B$ & 7 & 3 & 70 & 8 & 2 & 80 \\
\hline 53 & Arya Putra Pribadi & $8 B$ & 8 & 2 & 80 & 8 & 2 & 80 \\
\hline 54 & Farah Diva & $8 B$ & 8 & 2 & 80 & 8 & 2 & 80 \\
\hline 55 & Rovi W Mahawardhani & $8 B$ & 7 & 3 & 70 & 8 & 2 & 80 \\
\hline 56 & Adli Alghifari & $8 B$ & 8 & 2 & 80 & 8 & 2 & 80 \\
\hline 57 & Hesti Ramandhani & $8 B$ & 8 & 2 & 80 & 8 & 2 & 80 \\
\hline 58 & Neng Jihan Fertia Somantri & $8 B$ & 7 & 3 & 70 & 7 & 3 & 70 \\
\hline 59 & Senia Maulidya Rahayu & $8 B$ & 8 & 2 & 80 & 8 & 2 & 80 \\
\hline 60 & Jovinca $\mathrm{T}$ & $8 B$ & 7 & 3 & 70 & 7 & 3 & 70 \\
\hline 61 & Gishella Felicia & $8 B$ & 6 & 4 & 60 & 6 & 4 & 60 \\
\hline 62 & Angga Saputra & $8 B$ & 7 & 3 & 70 & 8 & 2 & 80 \\
\hline 63 & Khairu Hilal A & $8 B$ & 7 & 3 & 70 & 8 & 2 & 80 \\
\hline 64 & Sri Siti Patimah & $8 B$ & 8 & 2 & 80 & 9 & 1 & 90 \\
\hline 65 & M Zaldi Adenia & $8 B$ & 5 & 5 & 50 & 7 & 3 & 70 \\
\hline 66 & Roni & $8 B$ & 7 & 3 & 70 & 7 & 3 & 70 \\
\hline 67 & Dicky Dwi Darmawan & $8 B$ & 5 & 5 & 50 & 7 & 3 & 70 \\
\hline 68 & Silvani Rahayu & $8 B$ & 7 & 3 & 70 & 8 & 2 & 80 \\
\hline 69 & Novia Maharani & $8 B$ & 7 & 3 & 70 & 7 & 3 & 70 \\
\hline 70 & Taufik Hidayat Ar & $8 B$ & 8 & 2 & 80 & 8 & 2 & 80 \\
\hline 71 & Ihsan A & $8 B$ & 8 & 2 & 80 & 8 & 2 & 80 \\
\hline 72 & Nazwa Putri M & $8 \mathrm{~B}$ & 8 & 2 & 80 & 9 & 1 & 90 \\
\hline 73 & Claresya Syarah Maudy Z & $8 B$ & 6 & 4 & 60 & 6 & 4 & 60 \\
\hline 74 & Rovi W Mahawardhani & $8 B$ & 9 & 1 & 90 & 9 & 1 & 90 \\
\hline
\end{tabular}




\begin{tabular}{lllllllll}
\hline 75 & Pashasukmakencana & $8 \mathrm{~B}$ & 7 & 3 & 70 & 8 & 2 & 80 \\
76 & Arul Muhamad Kurniawan & $8 \mathrm{~B}$ & 4 & 6 & 40 & 6 & 4 & 60 \\
77 & Koswara & $8 \mathrm{~B}$ & 7 & 3 & 70 & 7 & 3 & 70 \\
\hline
\end{tabular}

The average distribution of students' knowledge about natural disaster mitigation both before and after being given exposure using power point media can be seen in Table 2 .

Table 2. Average Value of Sample Knowledge Before and After Socialization

\begin{tabular}{c|c|c}
\hline \multirow{2}{*}{ Mean } & Pre-test & Post test \\
\cline { 2 - 3 } & 71 & 76 \\
\hline
\end{tabular}

The frequency distribution of students' knowledge about disaster mitigation both before and after being given an explanation using power point media can be seen in Table 3 .

Table 3. Frequency Distribution of Sample Knowledge Before and After Socialization Using Power Point Media

\begin{tabular}{ccccc}
\hline Knowledge & \multicolumn{2}{c}{ Pre-test } & \multicolumn{2}{c}{ Post test } \\
\cline { 2 - 5 } & $\mathrm{N}$ & $\%$ & $\mathrm{~N}$ & $\%$ \\
\hline Good & 67 & $87 \%$ & 76 & $98 \%$ \\
\hline Not good & 10 & $13 \%$ & 1 & $2 \%$ \\
\hline Total & 77 & $100 \%$ & 77 & $100 \%$ \\
\hline
\end{tabular}

The results of this study can be categorized as good if the sample has a value greater than or equal to 60 and it is not good if the sample has a value less than 60.Based on the calculation of the results of the pretest conducted, before the socialization there were 67 or about $87 \%$ had good knowledge and as many as 10 or about $13 \%$ have poor knowledge. However, after the socialization was carried out, according to the calculation of the post-test results, those who had good knowledge increased to as much as 76 or around $98 \%$, while those who had poor knowledge were 1 or about $2 \%$.

In the natural disaster mitigation socialization program from an early age at SMP Negeri 1 Majalaya, Majalaya District, Bandung Regency, West Java, the implementers of the activity who are members of the research working group and together with field supervisors conduct socialization using power point media. This activity is expected to have a positive impact on the students of SMP Negeri 1 Majalaya both in the short and long term.

\section{Conclussion}

Based on the exposure to the results carried out with the indicators shown, students' knowledge has increased regarding natural disaster mitigation efforts. This is indicated by the percentage of students' knowledge before being given the material from $87 \%$, an increase after being given an understanding of natural disaster mitigation to $98 \%$. Increasing students' insights about natural disaster mitigation, in the long term students are ready to respond to disasters so that the impact of disasters can be minimized.

\section{References}

Efendi, D., Agustivara, \& Putra, H. A. (2019). Natural disasters management and the challenge of governability in Indonesia. Indian Journal of Public Administration, 65(3), 627-645. 
Kumala Dewi, L. P. R., \& Dartanto, T. (2019). Natural disasters and girls vulnerability: is child marriage a coping strategy of economic shocks in Indonesia?. Vulnerable children and youth studies, 14(1), 24-35.

Kurniasari, N., Haloho, H. N., \& Christian, A. E. (2019). Tourism Image Recovery Strategy Post-Natural Disasters in Indonesia. Jurnal IPTA, 7(2), 2019.

Kurniawan, D., Sutan, A. J., Nurmandi, A., \& Loilatu, M. J. (2021, July). Social Media as Tools of Disaster Mitigation, Studies on Natural Disasters in Indonesia. In International Conference on Human-Computer Interaction (pp. 375-382). Springer, Cham.

Mardiasmo, A., \& Barnes, P. (2015). Community response to disasters in Indonesia: Gotong Royong; a double edged-sword. In Proceedings of the 9th annual international conference of the international institute for infrastructure renewal and reconstruction (pp. 301-308). Queensland University of Technology.

Pascapurnama, D. N., Murakami, A., Chagan-Yasutan, H., Hattori, T., Sasaki, H., \& Egawa, S. (2016). Prevention of tetanus outbreak following natural disaster in Indonesia: lessons learned from previous disasters. The Tohoku journal of experimental medicine, 238(3), 219-227.

Pascapurnama, D. N., Murakami, A., Chagan-Yasutan, H., Hattori, T., Sasaki, H., \& Egawa, S. (2018). Integrated health education in disaster risk reduction: Lesson learned from disease outbreak following natural disasters in Indonesia. International Journal of Disaster Risk Reduction, 29, 94-102.

Pramono, J., Kusumastuti, D., Sekarwangi, M., \& Choerudin, A. (2020). The Community Participation in Disaster Mitigation to Managing the Impact of Natural Disasters in Indonesia. Journal of Talent Development and Excellence, 12(2s), 2396-2403.

Pratama, W. H., \& Sumitra, I. D. (2020, July). Utilization of Technology for Early Warning of Natural Disasters in Indonesia. In IOP Conference Series: Materials Science and Engineering (Vol. 879, No. 1, p. 012011). IOP Publishing.

Rindrasih, E., Hartmann, T., Witte, P., Spit, T., \& Zoomers, A. (2018). Travelling without a helmet: tourists' vulnerabilities and responses to disasters in Indonesia. Disasters, 42(4), 782-803.

Rush, J. V. (2018). The impact of natural disasters on education in Indonesia. Economics of disasters and climate change, 2(2), 137-158.

Sattler, D., Claramita, M., \& Muskavage, B. (2018). Natural disasters in Indonesia: Relationships among posttraumatic stress, resource loss, depression, social support, and posttraumatic growth. Journal of loss and trauma, 23(5), 351-365.

Seyle, D. C., Widyatmoko, C. S., \& Silver, R. C. (2013). Coping with natural disasters in Yogyakarta, Indonesia: A study of elementary school teachers. School Psychology International, 34(4), 387-404.

Kusumastuti, R. D., Husodo, Z. A., Suardi, L., \& Danarsari, D. N. (2014). Developing a resilience index towards natural disasters in Indonesia. International journal of disaster risk reduction, 10, 327-340.

Viverita, V., Kusumastuti, R. D., Husodo, Z. A., Suardi, L., \& Danarsari, D. N. (2014). Households perceptions on factors affecting resilience towards natural disasters in Indonesia. The South East Asian Journal of Management, 8(1), 13-28.

Wardani, S. P. R., \& Muntohar, A. S. (2013). Lessons Learned from the Recent Natural Disasters in Indonesia. In Geotechnical Predictions and Practice in Dealing with Geohazards (pp. 47-59). Springer, Dordrecht.

Yulianto, E., Yusanta, D. A., Utari, P., \& Satyawan, I. A. (2021). Community adaptation and action during the emergency response phase: Case study of natural disasters in Palu, Indonesia. International Journal of Disaster Risk Reduction, 65, 102557. 